\section{Citrus Research and Education Center at Lake Alfred, Fla., Celebrates 75 Years of Excellence}

The Univ. of Florida's Citrus Research and Education Center (CREC) at Lake Alfred is one of the world's largest and foremost research institutions devoted to a single commoditycitrus. Its multidisciplinary program focuses on virtually all facets of the citrus industryproduction, fresh-fruit handling, and processing. CREC enjoys a proud tradition of close partnership with the citrus industry of Floridaa partnership that began 75 years ago.

In 1917 the Florida legislature authorized the establishment of a Univ. of Florida experiment station for the investigation of problems facing citrus growers. This legislation required that the facility be funded entirely by donations from the state's growers. A committee of Polk County citrus growers in central Florida initiated a fund-raising campaign and collected more than $\$ 10,000$. A property consisting of 34 ha near the geographic center of Florida (the present site of CREC) was purchased for $\$ 5900$. This was a typical Ridge grove site with sandy soil and gently rolling hills and was ideally suited for growing citrus.

John H. Jefferies was appointed superintendent of the Citrus Experiment Station (CES) in Oct. 1920, with the responsibility y of overseeing the care of the groves. At that time, research was directed by scientists at the Florida Agricultural Experiment Station located on the main university campus in Gainesville. Faculty and staff had to travel the 125 miles from Gainesville to Lake Alfred to conduct their research.

In Oct. 1921 the first building at CES was constructed to house the superintendent. A portion of the house was used to accommodate the researchers visiting from Gainesville. Until July 1923 no state funds were appropriated by the state legislature to operate the experiment station, and only residual money from that collected by the Polk County committee was available to maintain the station. The legislature first appropriated state funds $(\$ 10,000)$ in 1924. In that year, a small laboratory building, consisting of a temporary frame structure, was constructed with funds from the Florida State Plant Board's Emergency Fund

By 1926, 25 ha of the station's land was planted for experimental work on citrus. The

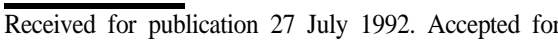
publication 15 Aug. 1992. Florida Agricultural Experiment Station Journal Series no. R-02600. The cost of publishing this paper was defrayed in part by the payment of page charges. Under postal regulations, this paper therefore must be hereby marked advertisement solely to indicate this fact.

Front cover: Ben Hill Griffin, Jr. Citrus Hall at CREC (photograph by Terri Zito, CREC staff ohotographer). first permanent Univ. of Florida faculty member was assigned to work on site in that year.

The first director of CES was appointed in 1935. Horticulturist Arthur Forrest Camp was transferred from the Gainesville campus he served as director for21 years, until his retirement in 1956. Under Camp's directorship, the Lake Alfred station became one of the world's foremost citrus research centers.

In 1941 the state legislature added a section to the Florida Citrus Code that allowed the Florida Citrus Commission to develop a scientific research department. Under state law, the commission's research division could only of citrus, a restriction that continues today. On 1 July 1947 the commission's team of scientists was transferred to CES in Lake Alfred. Since then, the Florida Dept. of Citrus (FDOC), whose revenue is derived from a box tax assessment to citrus growers, has continuously maintained scientific research at that location. John A. Attaway has served as FDOC's scientific research director since 1968. In the beginning, CES had only five researchers. The scientific staff, including those in the FDOC and U.S. Dept. of Agriculture, expanded steadily over the years, reaching 30 in 1948 and 61 in 1956. That number has remained more or less consistent.

After Camp's retirement, Herrnan J. Reitz was appointed CES director effective 1 Jan. 1957. Reitz had served as a horticulturist at Lake Alfred from 1949 until his appointment as director. In 1971, after 54 years of operation, the name of the Citrus Experiment Station was changed to the Agricultural Research and perform studies on the post-production aspects
Education Center (AREC) to conform to a policy for the statewide centers of the Institute of Food and Agricultural Sciences.

After directing the AREC for 25 years with distinction, Reitz retired in 1982. I succeeded Reitz and remain in that position. I had previously served as head of Cornell Univ.'s Pomology and Viticulture Dept. in Geneva, N.Y., and as chairman of the Dept. of Pomology in Ithaca, N.Y.

The name of the center was changed in 1984 to the Citrus Research and Education Center (CREC) to reflect its mission specifically. In 1992 the 60 faculty members, in a diversity of scientific disciplines, are affiliated with the Depts. of Horticultural Sciences, Food Science and Human Nutrition, Entomology and Hematology, Plant Pathology, Soil and Water Science, Food and Resource Economics, and Agricultural Engineering of the Univ. of Florida, Gainesville. The total staff at Lake Alfred continues to include the Univ. of Florida and the FDOC.

Horticulturists make up the Iargest faction of the Lake Alfred faculty, with 18 faculty positions in programs covering citrus rootstock, planting systems, root biology, citrus variety improvement and testing, cell culture and genetics, water resources, irrigation, reclaimed water use, freeze protection, weed control, stress physiology, growth regulation and crop control, and mechanical pruning. The development of nutrition practices that provide optimum levels of major and minor elements to grow citrus efficiently on central Florida's well-drained sandy soils has been a major accomplishment. Lake Alfred horticulturists also interact closely with scientists in other disciplines at the center. For example, engineering research on pesticide application technology, harvest methods, remote sensing, electronic grading, and soil-water-nutrient relations balances the horticulture/harvesting working group. The postharvest working group, consisting of six scientists in horticulture, plant pathology, and engineering, work on fruit quality improvement; fruit physiology, color,
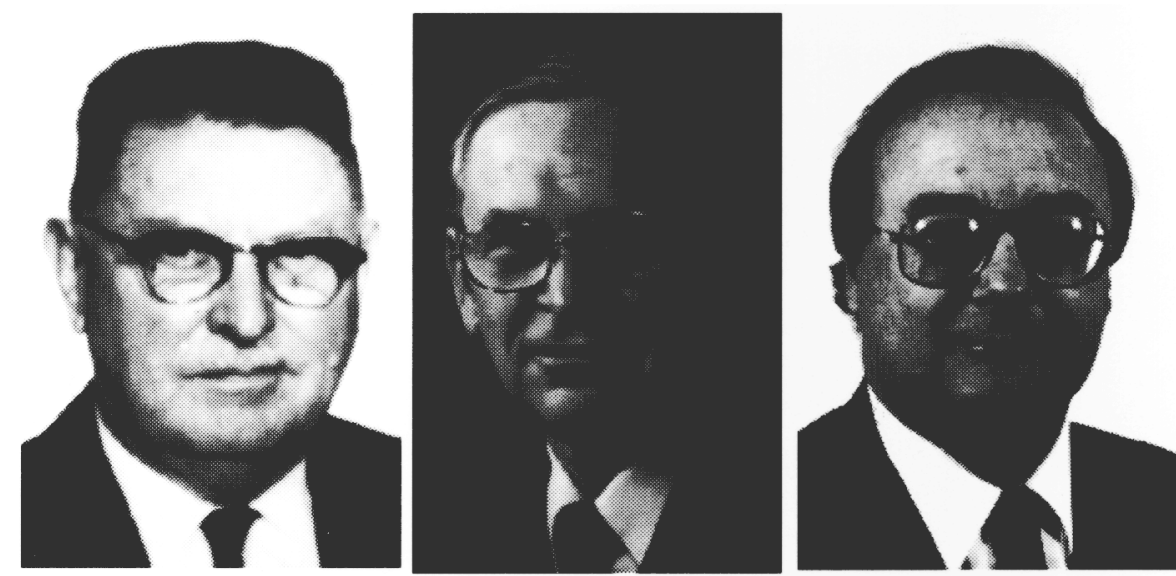

Fig. 1. Since 1935 the Citrus Research Station at Lake Alfred, Fla., has had three directors (left to right): Arthur F. Camp, Citrus Experiment Station (1935-56); Herman J. Reitz, Agricultural Research and Education Center (1957-82); and Walter J. Kender, Citrus Research and Education Center (1982present).

(continued on inside back cover) 
(continued from inside front cover)

and carbohydrate content; acid metabolism; decay control; postharvest handling; and quarantine treatment.

The citrus pathology perspective encompasses etiology, epidemiology, and disease management strategies for foliar, root, and fruit diseases of both fresh-market and processed citrus. Particular emphasis is on citrus blight, citrus tristeza virus, foliar and soilborne diseases, and postharvest pathology. The understanding of this etiology and control of the greasy spot fungus and the graft transmission of citrus blight disease are examples of important research conducted by the pathology working group. The reduction of citrus crop losses in Florida due to disease and the development of innovative and nonconventional methods for disease control continue to be major goals of the center.

The center's two hematologists and five entomologists investigate biological control of citrus insects, mites, and nematode pests and its integration into crop management systems. Major emphasis is directed toward nematode loss assessment, citrus-natural enemy interactions, insect-plant-chemical interactions, natural product toxicology, and mite control with natural enemies. Major contributions include the natural control of rust mites by fungal enemies and the linkage of spreading decline with the burrowing nematode. Alternative pest control strategies under investigation include the use of microbial pesticides on fire ants and other insects, pesticide benefit assessment, improved application methods, and citrus varieties with increased resistance to insects, mites, and nematodes.

Sixteen food scientists are engaged in seven areas of investigation, including: quality preservation and juice processing technology; specialty and by-product processing technology; microbial control and usage studies; food packaging systems and food oxidation studies; enzymatic problems and biochemistry studies; citrus processing engineering; and citrus color/ flavor studies.

The CREC biotechnology working group is using state-of-the-art recombinant DNA and cell culture methods to solve long-range problems related to citrus production and pro-

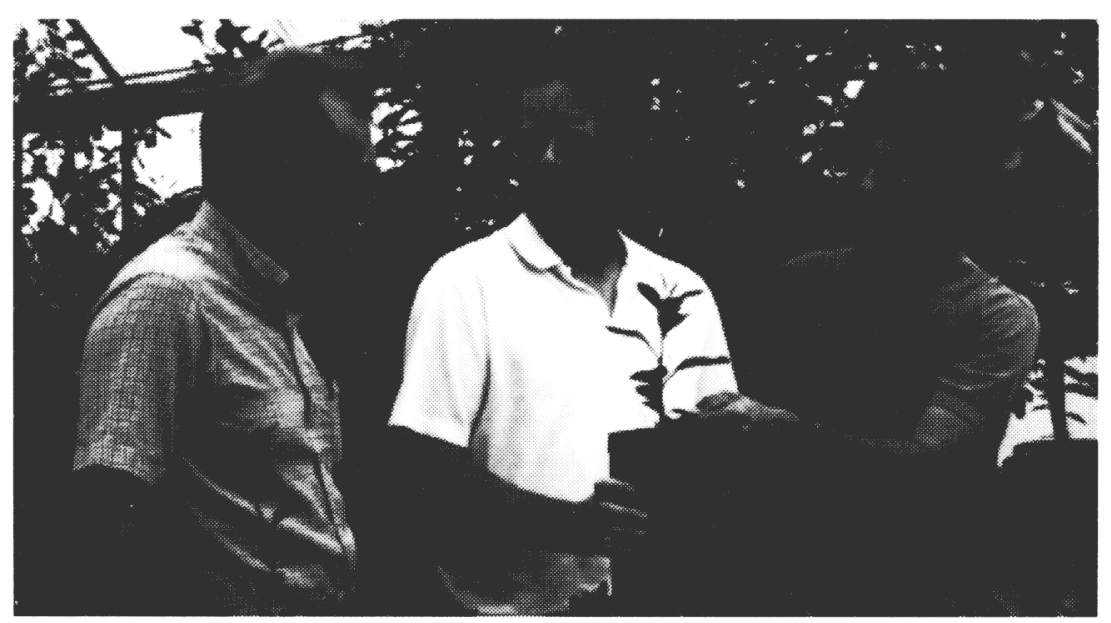

Fig. 2. Among the research programs at Lake Alfred is citrus rootstock and scion variety improvement. Principal investigators shown are (left to right): Bill Castle, rootstock horticulturist; Jude Grosser, cell geneticist; and Fred Gmitter, citrus breeder.

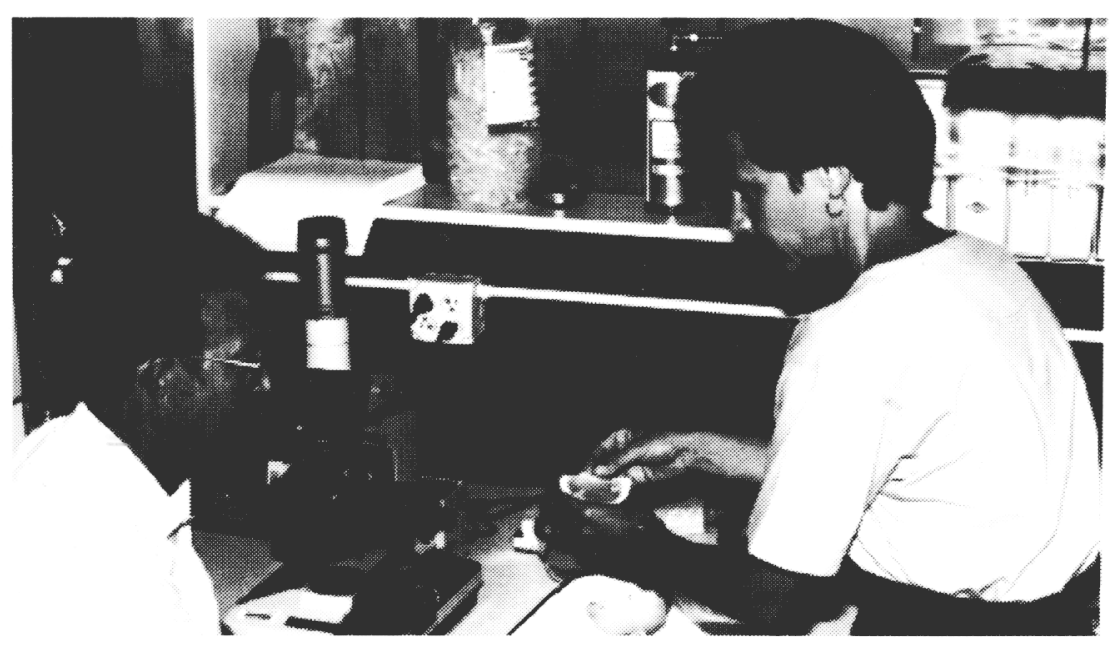

Fig. 3. Gene Albrigo (left) and Jacqueline Burns (right), postharvest physiologists at CREC, are members of the postharvest working group researching quality improvement of fresh citrus. cessing. The seven-member group includes scientists from the horticulture, plant pathology, and fruit processing working groups.

The extension service, an integral part of the center's total program, effectively transfers information at all levels between researchers and industry personnel through various communication methods to benefit the citrus industry. Many of Florida's citrus organizations meet at the center to conduct business and conferences as well as hold field days, short courses, and workshops. The seven extension faculty members at CREC are each associated with a working group. These extension specialists are vital links between the network of county agents and current research.

A series of citrus-related courses offered at CREC is part of the Univ. of Florida's graduate program. Graduate students conduct their research at the center, and dormitory facilities are available for housing. Several grant-supported postdoctoral research associates and visiting scientists are on the CREC staff.

From its modest beginnings, the Citrus Experiment Station at Lake Alfred has grown to a modern world-renowned center for the study of citrus science. CREC is unique among research stations worldwide. Because of its diversity and the depth of its programs, CREC provides strong, long-term statewide research leadership for solving immediate problems facing the industry as well as generating basic citrus knowledge on which to base future recommendations. After 75 years, CREC has achieved international prominence, which reflects strongly and positively on the Univ. of Florida's impact in the field of agriculture. CREC'S balance of basic and applied research, its viable extension information delivery systems, its educational opportunity, and its fostering of a multidisciplinary, interactive team approach is unequaled anywhere.

Lake Alfred scientists have made important contributions to science and to the citrus industry over the past 75 years. Services have been further enhanced in recent years through strong extension and teaching.

Applied and basic research has provided technical and scientific solutions for: 1) increasing the yield potential of citrus trees; 2) effectively controlling citrus losses from pests, diseases, and weeds; 3 ) enhancing fruit quality; 4) improving the importance of value added by the citrus industry; 5) processing and handling fresh citrus fruit more efficiently; and 6) integrating citrus production into Florida's future with urbanization, the environment, water resources, and its role in state, national, and global economies.

The center has a strong partnership with Florida's citrus industry. The support of citrus research has been a rewarding and sound investment of public and private funds.

W ALter J. KendeR Univ. of Florida Inst. of Food and Agricultural Sciences Citrus Research and Education Center 700 Experiment Station Rd. Lake Alfred, FL 33850 